\title{
Social innovation in managing diversity: Covid-19 as a catalyst for change
}

\begin{abstract}
Purpose: Covid-19 pandemic had an adverse impact on workforce diversity internationally. While in the Global North, many countries have sophisticated laws and organizational mechanisms and discourses to deal with such adverse impacts on workforce diversity, such structures of diversity management are either ceremonial or poorly developed in the Global South. The global pandemic disproportionately impacted Global North and Global South increases the existing gap due to vaccine rollout inequality and divergence in recoveries. We explore social innovation as a possible option for responding to the challenges induced by the Covid-19 pandemic.
\end{abstract}

Design/methodology/approach: The study draws on interviews in 26 distinctive organizations operating in various industries in Turkey. We have adopted a qualitative design to explore how social innovation helps to respond to diversity concerns during the Covid-19 pandemic.

Findings: We demonstrate that social innovation presents a viable option for a country with a poorly regulated context of diversity management. Social innovation could help overcome the challenge of the absence of supportive legislation, discourses, and practices of diversity in poorly regulated contexts.

Originality: The field study revealed several distinct forms of social innovation for diversity management, which emerged as a response to the Covid-19 pandemic. We demonstrate that in the absence of supportive diversity management structures and frameworks, social innovation in diversity management at the organizational level could provide a viable response to the emergent needs in the context of the Covid-19 pandemic.

Keywords: Global South, Covid-19, Diversity Management, Social Innovation, Working Mothers, Class Diversity, Emic Diversity Categories

\section{Introduction}

The World Health Organization (WHO) declared Covid-19 a global pandemic in March 2020. Since this declaration, studies have identified that the Covid-19 pandemic had an uneven impact by gender, ethnicity, disability, sexual orientation, age, social and economic class, and other socio-demographic categories. For example, the World Economic Forum (2021) survey shows that the pandemic had an adverse impact on gender and other forms of equality (UN, 2020). The pandemic exacerbated the inequalities between Global North and Global South (Worldbank, 2021). We address Global South as countries with less advanced economies and institutions, who have relatively less impact in international policymaking and economic decisions and the Global North as countries with more advanced economic, social and institutional systems and regulatory measures. Common to both the Global North and Global South, Covid-19 has reportedly increased gender gaps in countries such as Brazil, Canada, Colombia, Costa Rica, where women have been dropping out of the workforce market at a relatively higher rate than men in the pandemic (World Economic Forum, 2021). Although few studies were published on organizational responses to the Covid-19 in the Global North (Okonkwo, 2020; Sokol \& Pattaccini, 2020) there is limited research on how organizations in the Global South innovated to tackle workforce diversity challenges in Covid-19 (Saad-Filho \& Ayers, 2020). Drawing on a qualitative study in a country from the Global South where diversity management is 
ceremonially regulated by law, where organizations are not held accountable and responsible, and where discourses are not always supportive, we explore how organizations use social innovation for diversity management as an alternative approach to counteract the adverse impacts of the pandemic on workforce diversity. Our study reveals three categories of social innovation for workforce diversity. These are social innovations for working mothers, class, and other emic concerns. There are four emic social innovation categories specific to Turkey. These are social innovations for diversity by common birthplace bias, poverty, and digital literacy. The study demonstrates how social innovation could provide a viable alternative in contexts where diversity structures at the national, organizational, and discourse levels are poorly developed, as it is typical in the Global South. Thus, the study could shed light on how organizations in the Global South mobilize social innovation in order to promote and manage diversity in response to the Covid-19 pandemic.

\section{Theoretical framework: social innovation and diversity management}

The description of social innovation refers to developing innovative programs, services, and models to fulfill a social need (European Commission, 2011). Mulgan (2006:146) defines social innovation as "interventions to address a social need that are diffused through organizations whose primary purposes are social". SI focuses on blending people and communities' concerns as "integration of two key knowledge domains of business innovation and social awareness and the process of collective idea generation, selection and implementation by people who participate collaboratively to meet social challenges" (Dawson \& Daniel, 2010: 10). There are numerous reasons why profit-seeking organizations implement SI, such as attaining financial returns, increasing their societal impact, and adopting principles of environmentalism (Smith et al., 2020). Previous research has primarily explored social innovation within the domain of notfor-profit organizations (Pol\&Ville, 2009; Rueede \& Lurtz, 2012) and, elaborating SI within the domain of for-profit institutions needs further attention.

Social innovation can be utilized to address several social problems and needs of vulnerable groups, i.e., LGBT, black and ethnic minority groups, elderly, people with disabilities (Galego et al., 2021; Moulaert \& MacCallum, 2019). One of many social innovation methods that organizations implement includes building alliances, implementing green management techniques (Mirvins \& Googins, 2018), promoting volunteer work (de Wit, Mensink, Einarsson \& Bekkers, 2017) to create a deeper connection with the community, people and the environment. For example, for-profit companies implement social innovation via (i) social intrapreneurship, (ii) partnering with social entrepreneurs, (iii) pro bono problem solving via co-creation of innovative solutions with NGOs, and (iv) company-wide adoption of social innovation methods (de Wit, Mensink, Einarsson \& Bekkers, 2017). Pol and Ville (2009) argue that SI is the "generation and implementation of new ideas that carry the potential to improve the quality and quantity of work life". In this context, social innovation can be a novel method to manage workforce diversity in organizations.

Diversity management is defined as management approaches for managing differences in the workforce in response to normative and instrumental demands within and outside the organization (Pinnington et al., 2015). However, in recent years, diversity management interventions in modern organizations have received considerable criticism as most organizations have limited their diversity management efforts to training and education. Kalev and Dobbin (2020) and Noon (2018) have noted that equality and diversity training is necessary yet inadequate for effective diversity management. Kalev and Dobbin (2020) calls for innovative approaches to diversity management. Responding to the call for innovation for diversity management, we selected a national context, where diversity management happens voluntarily and is driven by organizational innovation alone. 
Major societal crises such as pandemics and global terrorism can harm workforce diversity. For instance, the Covid-19 pandemic has increased inequalities among various groups such as racial and ethnic minorities, including African Americans, Latin Americans, and Native Americans in the context of the USA (Okonkwo et al., 2020; ICNARC, 2020). Studies show deepening of the disadvantage due to the pandemic among Bangladeshi/Pakistani of the British Population (White \& Nafilyan, 2020), immigrants (Machado \& Goldenberg, 2021; Guttmann et al., 2020), women and working mothers in both developing and developed nations (Kalaylığlu, Öztürk \&Eker; 2020; Connor et al., 2020, Özkazanç-Pan \& Pullen, 2020; Nash \& Churchill, 2020; Vazquez-Vazquez, 2020); and socio-economic classes (Avery, 2021; Vesoulis, 2020). Additionally, pandemic-induced challenges such as government-imposed lockdowns and introduction of mandatory working from home (WFH) regulations heightened vulnerability of certain groups due to lack of adequate measures such as necessary infrastructure, appropriate living conditions, limited internet access, and caregiving possibilities (Mercer, 2020). Culmination of these adverse impacts call for social innovation in organizations to address the workforce diversity challenges associated with the Covid-19 pandemic.

\section{The Context}

In this section, we provide two contextual backgrounds. In the first one, we assess the impact of the global Covid-19 pandemic on workforce diversity in organizations. The second contextual subsection focuses on the case of Turkey, a country from the Global South with a toxic triangle of workforce diversity.

\section{The context of Covid-19}

The Covid-19 pandemic has revealed many vulnerabilities across fault lines of class, ethnicity, gender, and other diversity categories internationally. Recent research shows multilayered efforts to address these vulnerabilities and offers safety nets for communities and adversely affected individuals. A recent ILO (2020) report indicates that several governments and international unions provided essential support to vulnerable groups to tackle Covid-19 challenges in particular industries, including healthcare, food, retail, transport, and textile. For example, the Austrian government has paid an additional 500 Euros per immigrant worker in the healthcare industry, whereas the Czech Republic and Slovenia offered hazard pay to essential frontline workers (OECDa, 2021). However, the global pandemic has increased the inequalities among countries in Global South and Global North regarding vaccine rollout and divergence in recoveries. This circumstance also has a negative impact on economies of developing nations in the Global South. As David Malpass, the president of the World Bank Group, stated, "rising inflation, limited policy support, shortages in job and food supply" are few of the many obstacles that developing nations have experienced during Covid-19 (Worldbank, 2021).

Various international workers and employers' unions, such as the European Public Service Union (EPSU), the Federation of European Social Employers, European Federation of Food, Agriculture, and Tourism Trade Unions (EFFAT) have recommended governments to provide health and safety instructions and access to Personal Protective Equipment (PPEs) (ILO, 2020) to tackle the adverse effects of the Covid-19. Some companies provided essential frontline workers such as those in food and retail with appreciation bonuses (Acosta, 2020). Even though some of the progressive stances that international, national, and institutional interventions implemented, we still need to acknowledge that many organizations failed to deliver adequate supportive measures. So far, there are notable studies exploring the adverse gendered impacts of Covid-19. For example, the research identified that working mothers have considered

downshifting or leaving the workforce due to the pressures that they have experienced in balancing childcare and work demands (McKinsey, 2020). This circumstance may worsen the gender pay gap even 
further if companies maintain their performance appraisal mechanisms to hours spent at work, i.e. facetime (Alon et al.,2020). The Society of Human Resource Management suggested additional paid and unpaid leave to working mothers and childcare support to manage their exacerbated conditions (Lee, 2020). Social innovation is known as a mechanism to address social needs. In the extant literature, the studies explore the effect of Covid-19 on diversity management and adopted social innovation methods that emanate from countries and organizations with strong social welfare traditions and industrial democracies. As most advanced democratic countries have multifaceted approaches to managing diversity and equality, understanding social innovation in countries without well-developed approaches will provide new insights.

\section{The Turkish context}

Turkey has a context of a toxic triangle for workforce diversity (Kusku et al., 2021). It has ceremonial and ineffective legal arrangements for equality at work. It does not have state-mandated control over workplace practices that fight discrimination. It also lacks supportive discourses at the political and corporate levels to combat systemic inequalities. In such a context, innovation for diversity management becomes the only possible impetus for organizations if they wish to pursue diversity management. Turkey is an interesting country in which to study workforce diversity because it is the country that received the highest number of refugees and immigrants in Europe during the Syrian conflict (UNHCR, 2017). Women in Turkey are under considerable threat of violence and harassment due to traditionalism in politics and workplace relations. Turkey has a hostile gender and sexual orientation equality environment as there are entrenched forms of gender and sexuality-based violence (OECDb, 2021; UNDP, 2020). LGBT+ rights are also under threat as the Turkish ruling party has recently developed hostile discourses against LGBT+ rights (KAOS GL/Human Rights Watch, 2020). Turkey has recently withdrawn from the Istanbul Convention, which aimed to combat gender-based violence. Turkey's current context of equality and diversity means that organizations are left to their own devices to formulate diversity management approaches as there is no political, legal, and normative pressure to implement diversity interventions (Kamasak et al., 2020). We know little about how diversity management operates under Covid-19 pandemic rules in countries and organizations that lack strong normative, regulatory, and protective measures like welfare regimes and democratic approaches against discrimination and inequality.

Exploring how Turkish organizations socially innovate for diversity management in the absence of legal and normative pressures could provide interesting insights. The adverse impact of Covid-19 has exacerbated the existing gender inequalities and wage gap even further in Turkey since women are the primary caregivers (Republic of Turkey Ministry of Family, Labour and Social Services, 2016; 2018; Bozkurt 2020). Class diversity is also another salient diversity category which is negatively affected in pandemic conditions. Due to the government-imposed WFH, the existing class disparity has widened in Turkey, since the majority of the workforce is employed in manufacturing, food manufacturing, and retail, earning below the poverty line (roughly between 2450 and 3300 TL) (Turkish Ministry of Labor and Social Security, 2017). As only $24 \%$ of the current jobs in these industries are suitable for mandatory WFH conditions in Turkey (Aytun \& Özgüel, 2020). Thus, our study seeks to shed light to how SI can alleviate workforce diversity challenges associated with the Covid-19 pandemic.

\section{Method}

We have used qualitative methodology to explore how organizations mobilized social innovation in order to address the workforce diversity challenges in the Covid-19 pandemic in Turkey. The advantage of qualitative methodology in exploratory research is that the open-ended questions allow researchers flexibility, and findings can highlight culturally salient distinctions. For this purpose, we have administered 
semi-structured interviews with twenty-six human resources managers, directors, and HR business partners from various organizations, which operate in industries, such as retail, manufacturing, food manufacturing, and finance in Turkey. Our analysis focused on identifying the social innovation which were developed by these organizations in response to workforce diversity challenges of the Covid-19 pandemic. Our underlying logic was an abductive approach, enabling researchers to obtain sufficient insights by engaging "in a back and forth movement between theory and data to develop a new theory or modify existing theory" (Awuzie \& McDermott, 2017, p. 357). One of the benefits of the abductive method is that it enables the researcher "to recognize it as working through multiple levels of abstraction, starting with the raw data and forming larger and larger categories" (Creswell, 2007:43). The interview schedule had a semi-structured design, which allowed researchers flexibility and maintained control of the interview structure and focus (Creswell \& Miller, 2000). The qualitative survey instrument included semi-structured questions aimed to explore (i) existing diversity management approaches of the company, (ii) Covid-19 challenges in three specific time frames (March, June, and December), (iii) the methods implemented during Covid-19, (iv) the effects of the implemented social innovation methods on managing diversity.

\section{Sample, Data Access, and Data collection}

According to the ILO preliminary evaluation conducted during the Covid-19 pandemic, there is clear evidence that the crisis impacted industries, including food retail, textile and clothing, tourism and hospitality, education, civil aviation, meat packaging, and many more. This research focuses on companies operating in these industries, including retail (food and clothing), manufacturing (food and durable goods), finance and hospitality management operating in Turkey. The sample includes organizations from the specified distinctive industries which were affected by Covid-19.

Hendricks, Blanken \& Adriaans (1992) indicated that the snowball technique can be a primary source when the study's aim is exploratory, qualitative and the method then provides practicality. The research interviews are conducted in 2020 to examine the social innovation that organizations engaged in to tackle the adverse effects of Covid-19 on selected companies. The research is based on semi-structured interviews with key personnel, primarily human resource executives, responsible for increasing awareness and adopting programs to manage diversity in the organization and implementing social innovation measures taken during Covid-19. We focused on an organizational level analysis and the first author interviewed 26 human resource executives to explore social innovation methods for diversity management. The participants' selection process was based on their ability to provide us with the requisite organizational level data. Participant selection helped establish the study's data credibility (Graneheim, Lindgren \& Lundman, 2017:33). The interviewees were given a promise of anonymity and confidentiality of the interviews as per the ethical guidelines of the respective universities. Due to Covid-19 conditions, we have conducted interviews via video platforms. We have kept the company names confidential and referred to them with alphabetical acronyms irrespective of any hierarchical order. Our overall objective to data collection was to achieve insights into an understudied concept through substantial data collection on social innovation interventions to manage diversity in the Turkish context.

All interviews were recorded. Once an interview was completed, it was transcribed verbatim. All interviews were saved in password protected folders. The transcribed interviews were shared among the researchers, who read the material independently. After the initial discussion of the transcribed interviews, which resulted in a 27,000-word document, we analyzed and applied qualitative thematic data analysis techniques that led to interpretation and theorizing (Miles \& Huberman, 1994). The average interview lasted 40 minutes and was conducted by the first author of this paper. In order to attain cross-check of data validity and reliability, interviews are transcribed verbatim and were assessed by the co-authors of the paper. The 
respondents were human resource executives, and the majority of them (17) hold positions at the directorship level and are key personnel in implementing human resource practices. The demographic data regarding the participating organizations and the representatives whom we interviewed in order to garner organizational level data is provided below (Table I).

Table 1. Participating organizations, job title of interviewees and Industry Information

\begin{tabular}{|c|c|c|c|}
\hline Number & Company (pseudonyms) & $\begin{array}{l}\text { Job Title of the } \\
\text { Interviewee }\end{array}$ & Name of the Industry \\
\hline 1 & $\mathrm{AX}$ & HR director & Food manufacturing \\
\hline 2 & $\mathrm{BX}$ & CHRM & Retail (consumer goods) \\
\hline 3 & $\mathrm{CX}$ & HR-BP & Retail (clothing) \\
\hline 4 & $\mathrm{DX}$ & Regional HR director & Chemical (consumer goods) \\
\hline 5 & EX & HR BP & Retail (clothing) \\
\hline 6 & FX & HR director & Retail (Food) \\
\hline 7 & GX & HR manager & Manufacture (Household) \\
\hline 8 & $\mathrm{HX}$ & HR director & Finance (Participative Banking) \\
\hline 9 & IX & HR manager & Finance (Investment) \\
\hline 10 & JX & HR director & Retail (clothing) \\
\hline 11 & $\mathrm{KX}$ & HR director & Retail (clothing) \\
\hline 12 & LX & HR director & Food manufacturing \\
\hline 13 & MX & HR director & $\begin{array}{l}\text { Computer hardware and consumer } \\
\text { electronics }\end{array}$ \\
\hline 14 & NX & HR manager & Retail (clothing) \\
\hline
\end{tabular}




\begin{tabular}{|l|l|l|l|}
\hline 15 & OX & HR director & IT and service \\
\hline 16 & PX & HR director & Retail (clothing) \\
\hline 18 & QX & HR regional director & Retail (cosmetics) \\
\hline 19 & RX & HR manager & Retail (consumer goods) \\
\hline 20 & SX & HR director & Chemical (consumer goods) \\
\hline 21 & TX & HR director & Retail (food) \\
\hline 22 & UX & HR regional director & Retail (consumer goods) \\
\hline 23 & VX & HR manager & Food manufacturing \\
\hline 24 & WX & HR manager & Hospitality and tourism \\
\hline & YX & HR director & Hospitality and tourism \\
\hline
\end{tabular}

\section{Method of data analyses}

Data analyses involved thematic analysis of diversity management practices identified in each participating organization based on interview data with human resource officers in each organization. Data were coded across social innovation, which were designed in response to diversity challenges in the Covid-19 crises. In order to ensure intercoder reliability, three authors independently engaged in coding and analyses of the data. The general procedure in thematic analysis necessitates methodical codification of empirical data. It involves encoding qualitative data via utilizing explicit codes, leading to patterns recognized in the data (Braun \& Clarke, 2007). As the themes were emergent social innovation interventions for diversity management, the co-authors have identified these themes independently first and then decided their overall significance together in shaping the thematic analyses.

Lincoln \& Guba (1985) argues that to attain trustworthiness of a qualitative data, researchers need to assess credibility, dependability, conformability and transferability of the explored phenomenon. To establish credibility of the study, we have explored the same phenomenon across different organizations and considered only common underlying social innovation initiatives. We have refined multiple iterations and focused on key diversity aspects that are found in various organizations participating in this study to attain 
dependability. The first author collected the data, which queried interviewers to describe social innovations for diversity in the context of Covid-19. For conformability, after the first author collected the data, the data was collated and shared with the two co-authors who joined data analyses, coding, and selection of illustrative quotes. Each co-author independently identified significant diversity interventions on social innovation for diversity under Covid-19 conditions. Then co-authors got together to check their common and significant themes. When the two co-authors could not obtain a consensus, the theme was omitted or reconstructed until the researchers reached a complete consensus. In terms of transferability, the study could provide insights into diversity practices in emerging economy contexts with low levels of regulation. Initially, three significant themes were identified in the second revision of the paper, subsequently, this was reduced to two themes, and a third category of 'other emic interventions' was added, containing three emergent subthemes (Table 2).

Table 2. Thematic analyses of the data

\begin{tabular}{|l|l|l|l|}
\hline $\begin{array}{l}\text { Key social } \\
\text { innovation } \\
\text { categories for } \\
\text { diversity } \\
\text { management in } \\
\text { participating } \\
\text { organizations }\end{array}$ & $\begin{array}{l}\text { Organizational } \\
\text { interventions to address } \\
\text { the challenges }\end{array}$ & $\begin{array}{l}\text { Covid-19 } \\
\text { challenges that } \\
\text { related to the } \\
\text { emergent } \\
\text { diversity } \\
\text { management } \\
\text { concerns }\end{array}$ & Evidence from organizations \\
\hline Working mothers & $\begin{array}{l}\text { EAPs (in-house and fee for } \\
\text { service) } \\
\text { Online counseling } \\
\text { Informal virtual gatherings } \\
\text { Creative parenting (fee- } \\
\text { based) programs }\end{array}$ & $\begin{array}{l}\text { Psychological } \\
\text { concerns }\end{array}$ & $\begin{array}{l}\text { BX, CX, DX, EX, KX, PX, } \\
\text { UX, ZX }\end{array}$ \\
\cline { 2 - 4 } & $\begin{array}{l}\text { Flexible work design } \\
\text { Implementing distinctive } \\
\text { meeting schedules }\end{array}$ & $\begin{array}{l}\text { Productivity } \\
\text { concerns }\end{array}$ & BX, DX, EX, MX, OX, SX \\
\cline { 2 - 5 } & $\begin{array}{l}\text { Frequent internal corporate } \\
\text { communication } \\
\text { Town-hall meetings } \\
\text { (Corporate webinars) }\end{array}$ & Trust concerns & $\begin{array}{l}\text { AX, BX, IX, JX, LX, QX, TX, } \\
\text { YX }\end{array}$ \\
\cline { 2 - 5 } & $\begin{array}{l}\text { Advanced payment benefit } \\
\text { PPEs }\end{array}$ & $\begin{array}{l}\text { Financial } \\
\text { concerns }\end{array}$ & $\begin{array}{l}\text { EX, FX, HX, IX, LX, SX, TX, } \\
\text { WX, ZX }\end{array}$ \\
\hline Class diversity & Health concerns & AX, DX, FX, GX, LX \\
\hline
\end{tabular}




\begin{tabular}{|l|l|l|l|}
\hline & $\begin{array}{l}\text { Digitization of work } \\
\text { processes } \\
\text { Special designed } \\
\text { applications } \\
\text { Providing technical support }\end{array}$ & $\begin{array}{l}\text { Productivity } \\
\text { concerns }\end{array}$ & $\begin{array}{l}\text { AX, BX, DX, FX, GX, LX, } \\
\text { MX, ZX, }\end{array}$ \\
\cline { 2 - 4 } & $\begin{array}{l}\text { Participating in social- } \\
\text { mission driven } \\
\text { campaigns/pro-bono } \\
\text { ventilators } \\
\text { "Biz bize yeteriz" (United } \\
\text { we stand) }\end{array}$ & $\begin{array}{l}\text { Engagement } \\
\text { concerns }\end{array}$ & CX, GX, HX \\
\hline $\begin{array}{l}\text { Emic concerns: } \\
\text { Digital illiteracy } \\
\text { Poverty/low }\end{array}$ & $\begin{array}{l}\text { Six Sigma Principles in } \\
\text { Biring and promotion } \\
\text { processes } \\
\text { Thorough background check } \\
\text { on kinship via digital } \\
\text { applications }\end{array}$ & $\begin{array}{l}\text { Health concerns } \\
\text { and financial } \\
\text { concerns }\end{array}$ & AX, DX, FX, GX LX, NX, VX, \\
\hline
\end{tabular}

Our key focus in developing the codes and categories of themes was on organizational motives and key drivers for adopting unique social innovation methods implemented to manage diverse workforce during Covid-19 in profit-oriented contexts. In addition, thematic analysis has granted researchers to develop categories of themes to explore the scope of our understanding of social innovation implementation in diversity management and company methods ranging from company-wide adopted employee assistance programs (EAP) to investing in digital tools. These categories will be further discussed when we present the research findings. In the study, we have identified specific vulnerabilities and emerging social needs during the Covid-19 pandemic. These vulnerabilities include working mothers, social-class inequalities, and other emic concerns such as digital illiteracy, poverty/low income, birthplace origin. Each group has faced distinctive challenges, and companies that participated in this study implemented various social innovation methods to alleviate the pandemic's negative impact.

\section{Research Findings}

We conducted organizational level analysis of social innovation interventions that organizations developed to tackle diversity challenges during the pandemic. The analyses revealed three distinctive social innovation interventions for diversity management in participating organizations. First, there were social innovations which considered the challenges facing working mothers. Second, there were social innovations for managing class diversity concerns. Third, there were idiosyncratic local diversity management categories, which we clustered as emic concerns.

\section{Social innovation for working mothers}

The first categorization of social innovation for diversity management is working mothers, and the companies have carried out various employee assistance programs to minimize the pandemic's impact on working mothers. EAP is a comprehensive program implemented during Covid-19 to tackle disputes among 
coworkers, financial issues, and stress-related problems. As the extant literature suggests, employee assisted programs are effective diversity management mechanisms since they positively minimize systemic inequalities (Frey, 2020). In our study, the interviewees indicated that companies implemented various inhouse and fee-based employee assisted programs such as counseling, creating virtual gatherings and programs to address, in particular, working mothers' challenges. Additionally, companies provided flexible work arrangements designed for working mothers and frequently utilized corporate communication to increase transparency and minimize work-related stress. As women do care work five times more than men in Turkey (Republic of Turkey Ministry of Family, Labour and Social Services, 2018), the semi-structured interviews of this study revealed that working mothers with school-aged children experienced adverse psychological effects of Covid-19, such as heightened levels of burnout and distress. Several participating companies implemented employee assisted programs specifically designed for working mothers, such as virtual gatherings with keynote speakers on motherhood issues and addressing parental issues via informal gatherings to manage these negative effects.

"We have implemented a "creative parenting" program. In this consecutive 5-day program, we collaborated with an external consultant kicked off with various educational materials to raise awareness of Covid-19 related parental challenges and included different school-aged children's recommended activities to increase parent-child bondage. The program started and ended with an expert psychologist on this matter". (Company $E X)$.

Some of the participant companies exclusively designed "experience labs" and gathered crossfunctional teams to recognize working mothers' needs during the pandemic.

"Implemented Persona studies to understand the challenges of this diverse group since they experienced the biggest challenge, women with children.... They do not have support for house choirs, so on one end, they are trying to cook and help their kids to connect to distance learning and try to participate in virtual company meetings all at once. We have prioritized this group and implemented multi-focus studies on issues such as at-home activities with their children, conducted webinars and meetings to help time management and provided psychological support". (Company BX)

As social innovation is related to implementing ideas and methodologies addressing social needs, working mothers' vulnerability has steadily increased during Covid-19. Addressing these social needs of working mothers is vital for long-term organizational effectiveness since an unsuccessful response to the gendered impact of Covid-19 may result in long-term economic challenges (Özkazanç-Pan \& Pullen, 2020). Although the participating companies have implemented flexible work arrangements designed for working mothers, the work schedules still need to be negotiated with immediate managers. Adopting remote working conditions through the lenses of genderneutral aspects may result in cost saving in the short term; however, in a country where childcare and household responsibilities are predominantly women's burden, organizations need to implement more concrete social innovation interventions to tackle the challenges.

Social innovation for class diversity 
Neo-liberal economic programs and privatization efforts in Turkey have increased the expansion of the working class. Majority of the households operate under the poverty line (Karaçimen, 2015), laborers constituted the majority of the poor in Turkey (Bahçe \& Köse, 2017). Implementing mandatory working from everywhere in Turkey has reportedly caused numerous obstacles due to inadequate technology (17\%), weak organizational structure (20\%), incompatible organizational culture and norms (43\%), feeling of isolation and alienation from work teams (KPMG, 2020). As only $24 \%$ of the current jobs in food retail and manufacturing are suitable for working from everywhere conditions (Aytun \& Özgüel 2020), this workforce bears a heightened exposure to health risks and economic challenges during the pandemic (Turkish Ministry of Health, 2021) as well. Culmination of these factors had a more adverse effect on working class people than on middle and upper class individuals who could comply with the imposition of working from home. The participating companies implemented several social innovation measures in digital solutions to alleviate the class divide in health risk exposure, such as using radio frequency tags to facilitate contact tracing and providing personal protective equipment (PPEs).

"The number of people has been reduced; we rescheduled the working hours, so when they meet each other in groups, anyone who is in contact with one another can be traceable for contact tracing. We have given radio frequency-tags to each employee so that we can do the tracing electronically." (Company $Z X)$.

Furthermore, as one of the explicit consequences of neoliberalism and privatization in developing nations resulted in deterioration of income distribution and increasing the prices of needs and services (Bahçe \& Köse, 2017), the majority of working class individuals were unable to adapt to digitization efforts due to their limited financial resources. Therefore, to manage the emerging needs of this workforce, the human resource department collaborated with information technology departments and designed applications suitable for their possession of digital devices. Furthermore, human resources regularly checked the penetration rate and provided necessary technical support. Therefore, it is possible to indicate that companies have tried to minimize inequality due to class disparity as they have tried to create inclusivity via implementing specific social innovation measures to alleviate emerging pandemic-related divisions in social needs.

"We thought and talked about the digitization of operational and other processes due to Covid-19 challenges. Our hourly-rate workforce has old cell phones, and they are not familiar with the internet, and we have 22,000 employees at this current point. We needed something feasible for those who needed to obtain documents, procedures, and related health measures implemented" (Company GX).

\section{Social innovation for emic diversity concerns}

Some of the companies invested in developing company-specific social innovation interventions such as digital applications. For example, food retailing companies have shifted to digital platforms to manage daily operations under government-imposed lockdown conditions such as uploading necessary "lockdown movement permits." However, as the digital literacy of those employed in food retailing and manufacturing is relatively low, the companies ensured that these applications are designed in a user-friendly way. Furthermore, participating companies implemented several 
payroll advances to ease the workforce's economic conditions. In Turkey, the Short-term Working Allowance Regulation has created challenges such as financial insecurity for the workforce who earn low income. Some of the participant companies adopted social innovation methods such as engaging external partnerships with consultant firms to operationalize a smoother process with the Turkish Employment Agency (İŞKUR) to minimize inefficiencies of this regulation. Also, some of the participant companies implemented social innovation methods such as engaging in social mission-driven projects to motivate the workforce. For example, a manufacturing company with a core competency in manufacturing household appliances, specifically manufactured ventilators, and others participated in government-led campaigns as "Biz Bize Yeteriz Türkiye'm" (United we stand) to respond to Covid-19 challenges and to motivate the workforce diversity. The participating human resource key personnel indicated that companies digitized human resource and work-related processes to maximize efficiency, provided payroll advance policies to minimize financial insecurity, and were involved in social-mission-driven support programs and campaigns that helped companies increase employee morale commitment while addressing a social need.

"What we did [offering substantial protective measures against Covid-19 transmissions] was an incredible motivation for the employees. This is because at the end of the day you are creating a benefit for society.... we did not tell them to come to work and do the work; we did not even calculate the economic benefit of this campaign ....I think it had a great impact, it gave a sense of belonging in Covid-19. In our engagement surveys, we have seen 3-point increase, and this is substantial" (Company GX).

One other social innovation that focused on emic diversity in this study was birthplace (hemsehri in Turkish). Birthplace in the Turkish context bestows people certain responsibilities of care for and privileged access to those who are born in the same city or region. In Turkey, rural to urban migration resulted in the condensation of birthplace diversity in manufacturing industries as these immigrants form strong networks in the urban context through their birthplace affiliations. Having a common birthplace results in upward mobility for people in the same birthplace network. Our study revealed that people who are excluded from a particular birthplace network face (i) increased job insecurity, (ii) financial challenges including adequate wages and (iii) fringe benefits, and (iv) health-related concerns. Since the pandemic exacerbated current conditions in attaining job opportunities, participating organizations sought to innovate in order to eliminate birthplace based bias in human resource management systems. For example, they implemented ongoing background checks on kinship for referrals to minimize common birthplace bias in work units. In order to achieve this, the participating companies mentioned that transparency and objective measures are critical.

"In particular, we have developed a test system to prevent the condensation of birthplace bias in our company. If a candidate passes the test, then the person is included in the interview process... We have reduced the feedback of a foreman to ten percent in the performance system. In this way, the employee cannot indicate comments such as "the foreman does not love me, he does not like my eye." In other words, we minimized these dialogues, it made our life easier, or we used to have many complaints about this situation in the past (Company LX) 
Some of the participating companies operating in the food manufacturing utilized Kaizen and Lean Six Sigma principles to improve work processes, such as implementing ongoing on-site training with smaller work units, providing a safe work environment, creating objective performance appraisals criteria to prohibit common birthplace bias within work units as birthplace bias is a relatively common issue in the manufacturing industry.

\section{Discussion and Conclusion}

Most advanced democracies in the Global North have taken adequate steps to study and combat the adverse consequences of the Covid-19 pandemic on workforce diversity with variable consequences. However, as Stiglitz (2019) predicted, countries with liberal market economies in the Global South, which typically have limited supportive and regulatory provisions for workforce diversity, have experienced even more substantial negative impacts on their workforce diversity. The disproportionate effects of the global pandemic have shown that the existing gap has increased among nations due to vaccine rollout inequality and divergence in recoveries. The global pandemic has severely affected those countries with sectoral landscapes similar to those of Turkey, i.e. dominated by services, manufacturing, tourism and retail (Alcazar et al., 2021). Therefore, studying social innovation for diversity management in Turkish organizations sheds light on the blackbox of organizational responses to diversity challenges imposed by Covid-19 in the Global South. Our study provides a partial contestation to the notion of woke capitalism (Rhodes, 2021) in the Global North, where companies usurp ideas of social movements, diversity and inclusion for their own instrumental ends to the detriment of democracy. We reveal that organizations in Turkey use social innovation to address their diversity challenges, even though there are no normative, legislative or policy imperatives for them to do so. In the absence of democratic mechanisms, it is social innovation that these organizations bring to provide inspiration for mimetic and isomorphic mechanisms by which diversity management practices are spread and adopted. Therefore, our evidence suggests that capitalist interests do not directly harm the democratic processes but, to an extent, may serve to diffuse democratic ideas (Pinnington et al., 2015), when no other normative or institutional pressure exist. Particularly in the weak regulatory regimes of the Global South, the relationship between capitalism and democracy is not settled in the same way as it is in the Global North.

This study provides new insights into how diversity concerns are addressed through social innovation in a context with low levels of diversity and equality regulation. Nevertheless, the organizations that we studied in Turkey have used social innovation to measure, monitor, and address workforce diversity needs, even though the national and institutional level treatment of workforce diversity remains adversarial. Thus, our study illustrates that even in more toxic and antagonistic contexts of workforce diversity, social innovation at the level of organizations could provide a viable option for dealing with the impact of the Covid-19 pandemic on vulnerable groups within workforce diversity. Our study revealed that in Turkey, where there is a toxic triangle of workforce diversity, there are three distinct social innovation interventions based on supporting working mothers, class, and emic diversity concerns.

As social innovation can be viewed as a method of tackling rising social issues (Cajaiba-Santana, 2014; Moulaert, Martinelli, Swyngedouw \& González, 2005), the increasing needs of emerged diversity categories of this study were addressed through social innovation mechanisms to (i) lower the experienced stress and anxiety related to Covid-19 conditions, (ii) provide organizational support to manage obstacles that may hinder performance, and (iii) strengthen mental health and well-being while increasing social belonging to the community. In the Turkish case, working mothers were specifically targeted as a vulnerable group for social innovation. Participating organizations went beyond the law and common practice to combat the negative consequences of Covid-19 pandemic on working mothers. Similarly, the 
participating organizations identified the widening class divide in Turkey as problematic and worked to offer safety nets for the growing working poor in their workforce through social innovation. Further, there were three emic social innovation interventions including addressing the digital divide between digitally competent and digitally illiterate workforce. Organizations sought to provide technological and social support to the latter group in order to address the negative impact of Covid-19 pandemic on this group. Organizations also sought to combat increased poverty among their staff at the lower echelons with interventions and measures beyond law. Finally, organizations fought against an emic diversity concern, i.e. common birthplace bias among their workforce by introducing bias eliminating strategies to combat the negative network effects which workers could suffer if decisions are made on arbitrary measures based on a common birthplace.

\section{References}

Acosta, G. (2020). How Coronavirus Is Changing Grocery. Retrieved from https://www.bizcommunity.com/Article/196/182/201952.html.

Alon, T., Doepke, M., Olmstead-Rumsey J. \& Tertilt, M. (2020). The Impact of COVID-19 on Gender Equality. NBER Working Papers 26947, National Bureau of Economic Research, Inc.

Avery, D. (2020). Lessons from the Losing: Implications of the COVID-19 Pandemic for Organizational Diversity Scholarship and Practice. Journal of Management Studies, 57(8), 1746-1749.

Aytun U. \& Özgüzel C. (2020) COVID-19 Sonucunda Evden Çalışabilirlik ve Eşitsizliğe Etkileri: Türkiye İçin Politika Önerileri. Istanbul: Istanbul Politik Araştırmalar Enstitüsü.

Awuzie, B., \& McDermott, P. (2017). An abductive approach to qualitative built environment research: A viable system methodological exposé. Qualitative Research Journal, 17(4), 356-372.

Bahçe, S. \& Köse, A. H. (2017). Social Classes and the Neo-Liberal Poverty Regime in Turkey, 20022011, Journal of Contemporary Asia, DOI: 10.1080/00472336.2017.1325919.

Bozkurt, V. (2020). Pandemi döneminde çalışma: ekonomik kaygılar, dijitalleşme ve verimlilik [Working during the pandemic: economic concerns, digitization and efficiency]. In D. Demirbaş, V. Bozkurt, S. Yorğun (Eds.), Covid-19 pandemisinin ekonomik, toplumsal ve siyasal etkileri [Economic, social and political effects of the covid-19 pandemic] (pp. 115-136). İstanbul, Turkey: İstanbul Üniversitesi Yayınevi.

Braun, V. and Clarke, V. (2006) Using Thematic Analysis in Psychology. Qualitative Research in Psychology, 3, 77-101.

Cajaiba-Santana, G. (2013). Social innovation: Moving the field forward. A conceptual framework. Technological Forecasting and Social Change, 82, 42-51.

Creswell, J. W. \& Miller, D. L. (2000). Determining validity in qualitative inquiry. Theory Into Practice, 39(3), 124-130, DOI: 10.1207/s15430421tip3903_2.

Creswell, J. W. (2007). Qualitative inquiry and research design: Choosing among five approaches (2nd ed.). London: Sage Publications.

Connor, D. B., Aggleton, J. P., Chakrabarti, B. , et al. (2020). Research priorities for the COVID-19 pandemic and beyond: A call to action for psychological science. British Journal of Psychology, 111(4), 603-629.

Dawson, P., \& Daniel, L. (2010). Understanding social innovation: a provisional framework. International Journal of Technology Management, 51(1), 9-21. doi:10.1504/ijtm.2010.033125.

De Wit, A. Mensink, W., Einarsson, T \& Bekkers, R. (2017). Beyond Service Production: Volunteering for Social Innovation. Nonprofit and Voluntary Sector Quarterly, 48(2). DOI: 089976401773465.

EC, European Commission. (2011). Empowering people, driving change: Social innovation in the European Union. Bureau of the European Policy Advisers, European Commission. 
Frey, J. J. (2020). How Employee Assistance Programs Can Help Your Whole Company Address Racism at Work.Harvard Business Review, October 14, 2020. Retrieved from https://hbr.org/2020/10/howemployee-assistance-programs-can-help-your-whole-company-address-racism-atwork?ab=at articlepage _relatedarticles horizontal slot1.

Galego, D, Moulaert, F, Brans, M, Santinha, G. (2021) Social innovation and governance: a scoping review. Innovation: The European Journal of Social Science Research. DOI: 10.1080/13511610.2021.1879630.

Graneheim, U. H. , Lindgren, B. \& Lundman, B. (2017). Methodological challenges in qualitative content analysis: A discussion paper. Nurse Education Today, 56, 29-34.

Guttmann A, F. et al. (2020), COVID-19 in Immigrants, Refugees and Other Newcomers in Ontario: Characteristics of Those Tested and Those Confirmed Positive, as of June 13, 2020, ICES, http://www.ices.on.ca.

Hendricks, V. M., Blanken, P. and Adriaans, N. (1992) Snowball Sampling: A Pilot Study on Cocaine Use, Rotterdam: IVO.

ICNARC. (2020). ICNARC report on COVID-19 in critical care. Retrieved from https://www.icnarc.org/Our-Audit/Audits/Cmp/Reports.

ILO. (2020). ILO Monitor: COVID-19 and the world of work. Third edition - Updated estimates and analysis. Retrieved from https://www.ilo.org/global/topics/coronavirus/ impacts-andresponses/WCMS_755910/lang--en/index.htm.

Kalaylığlı, Y., Öztürk, A. M. \& Eker, G. (2020). The economic and social impact of COVID-19 on women and men: Rapid Gender Assessment of COVID-19 implications in Turkey. UN Women Turkey Office. Retrieved fromhttps://www2.unwomen.org/-/media/field\%20office\%20eca/attachments/ publications/2020/06/rapid\%20gender\%20assessment\%20report\%20turkey.pdf?la=en\&vs=438.

Kalev, A. \& Dobbin F. (2020). Companies need to think bigger than diversity training. Retrieved from https://hbr.org/2020/10/companies-need-to-think-bigger-than-diversity-training.

Kamasak, R., Özbilgin, M. F., Baykut, S., \& Yavuz, M. (2020). Moving from individual intersections to institutional intersections: Insights from LGBTQ individuals in Turkey. Journal of Organizational Change Management, 33(3): 456-476.

Karaçimen, E. (2015). Interlinkages Between Credit, Debt and the Labour Market: Evidence from Turkey. Cambridge Journal of Economics, 39 (3):751-767.

KAOS GL. (2020). Human Rights Of Lgbti+ People In Turkey Report: There is an increase in violations caused by public authorities!. Retrieved from https://kaosgl.org/en/single-news/human-rights-oflgbti-people-in-turkey-report-there-is-an-increase-in-violations-caused-by-public-authorities.

Kusku, F., Arac1, Ö. \& Ozbilgin, M. (2021). What happens to diversity at work in the context of a toxic triangle? Accounting for the gap between discourses and practices of diversity management. Human Resource Management Journal, 31(2):553-574.

KPMG. (2020). Covid-19 Gündemi: Yeni Gerçeklikte Makro Trendler. Retrieved from https://assets.kpmg/content/dam/kpmg/tr/pdf/2020/07/covid-19-gundemi.pdf.

Lee,T. (2020). New SHRM Research on How COVID-19 Is Changing the Workplace. Retrieved from https://www.shrm.org/hr-today/news/hr-news/pages/new-shrm-research-on-how-covid-19-ischanging-the-workplace.aspx.

Lincoln, Y. S., \& Guba, E. G. (1985). Naturalistic inquiry. Beverly Hills, Calif: Sage Publications.

Machado, S., Goldenberg, S. (2021). Sharpening our public health lens: advancing im/migrant health equity during COVID-19 and beyond. Int Journal for Equity in Health, 20: 57 https://doi.org/10.1186/s12939-021-01399-1

Mckinsey Company. (2020). Women in the Workplace 2020. Retrieved from https://www.mckinsey.com/featured-insights/diversity-and-inclusion/women-in-the-workplace. 
Mercer (2020). Leading through the pandemic. Retrieved from https://www.mercer.us/content/dam/mercer/attachments/north-america/us/us-2020-leadingthrough-the-pandemic-survey-summary-report.pdf.

Miles, M. B. \& Huberman, A. M. (1994). Qualitative data analysis. London: Sage Publications.

Mirvins, P. \& Googins, B. (2018). Engaging Employees as Social Innovators. California Management Review, 60(4): 25-20.

Moulaert, F., \& MacCallum, D. (2019). Advanced Introduction to Social Innovation. Cheltenham, UK; Northampton, Massachusetts, USA: Edgar Elgar Publishers.

Moulaert F, Martinelli F, Swyngedouw E, Gonzalez S. Towards Alternative Model(s) of Local Innovation. Urban Studies, 42(11):1969-1990. doi:10.1080/00420980500279893.

Mulgan, G. (2006). The Process of Social Innovation. Innovations: Technology, Governance, Globalization, MIT Press, 1(2),:145-162.

Nash M \& Churchill B. (2020). Caring during COVID-19: A gendered analysis of Australian university responses to managing remote working and caring responsibilities. Gender Work Organ. 2:10.1111/gwao.12484. DOI: 10.1111/gwao.12484.

Noon, M. (2018). Pointless Diversity Training: Unconscious Bias, New Racism and Agency. Work and Employment Society, 32(1). doi: 10.1177/0950017017719841.

OECD. (2021a). OECD Employment Outlook 2021 : Navigating the COVID-19 Crisis and Recovery. Retrieved from https://www.oecd-ilibrary.org/sites/5a700c4ben/1/3/1/index.html?itemId $=/$ content/publication/5a700c4ben\& $\operatorname{csp}=\mathrm{d} 31326 \mathrm{a} 7706 \mathrm{c} 58707 \mathrm{~d} 6 \mathrm{aad} 05 \mathrm{ad} 9 \mathrm{dc5} \mathrm{ab} \& \mathrm{itemIGO}=$ oecd\&itemContent Type=book.

OECD. (2021b). Violence against women. DOI: 10.1787/f1eb4876-en (Accessed on 14 March 2021).

Okonkwo NE, Aguwa UT, Jang M, et al. (2020). COVID-19 and the US response: accelerating health inequities. BMJ Evid-Based Med. Published online June 3, 2020. https://doi.org/10.1136/bmjebm2020-111426.

Özkazanç-Pan B, Pullen A. Gendered labor and work, even in pandemic times. Gender Work Organ. 2020;27:675-676. 10.1111/gwao.12516.

Pinnington, A., Alshamsi, A., Karatas-Ozkan, M., Nicolopoulou, K., Ozbilgin, M., Tatli, A., \& Vassilopoulou, J. (2015). Early organizational diffusion of contemporary policies: Narratives of sustainability and talent management. Procedia-Social and Behavioral Sciences, 213, 807-811.

Pol, E. \& Ville, S. (2009). Social innovation: Buzz word or enduring term?. The Journal of social economics, 3, 878-885.

Republic of Turkey Ministry of Family, Labor and Social Services. (2016). Research on Family Structure. Retrieved from https:/ailevecalisma.gov.tr/uploads/athgm/uploads/pages/indirilebiliryayinlar/research-on-family-structure-in-turkiye-2013-findings-and-recommendations.pdf.

Republic of Turkey Ministry of Family, Labour and Social Services. (2018). Family Structures in Turkey: Advanced Statistical Analysis. Retrieved from https://www.ailevecalisma.gov.tr/media/35868/taya-18 ingilizce_kitap.pdf.

Republic of Turkey Ministry of Internal Affairs. (2021). Kademeli Normalleşme Tedbirleri Genelgesi. Retrieved from https://www.icisleri.gov.tr/kademeli-normallesme-tedbirleri-genelgesi .

Rhodes, C. (2021). Woke capitalism: how Corporate Morality is Sabotaging Democracy. Bristol: Bristol University Press.

Rueede, D. \& Lurtz, K. (2012). Mapping the Various Meanings of Social Innovation: Towards a Differentiated Understanding of an Emerging Concept. EBS Business School Research Paper No.

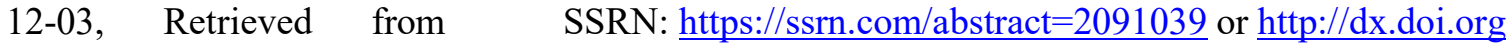
110.2139/ssrn.2091039.

Saad-Filho, A. \& Ayers, A. (2020). A ticking time-bomb': The global south in the time of coronavirus. The Journal of Australian Political Economy, 85, 84-93. 
Smith, K., Bhui, K. \& Cipriani, A. (2020). COVID-19, mental health and ethnic minorities. EvidenceBased Mental Health,23:89-90.

Stiglitz, J. E. (2019). People, Power, and Profits: Progressive Capitalism for an Age of Discontent WW Norton \& Company.

Sokol, M. \& Pataccini, L. (2020). Winners and losers in coronavirus times: financialisation, financial chains and emerging economic geographies of the covid-19 pandemic. Journal of Economic and Humann Geography, 111 (3), 401-415.

Turkish Statistical Institute (TUIK). (2020a). İşgücü istatistikleri 2020. Retrieved from https://data.tuik.gov.tr/Bulten/Index?p=Isgucu-Istatistikleri-2020-37484.

Turkish Statistical Institute (TUIK). (2020b). Retail Sales Indices, December 2020. Retrieved from https://data.tuik.gov.tr/Bulten/Index?p=Retail-Sales-Indices-December-2020-37355\&dil=2

United Nations. (2020). The impact of COVID-19 on women. Retrieved from https://www.unwomen.org//media/headquarters/attachments/sections/library/publications/2020/policy-brief-the-impact-ofcovid-19-on-women-en.pdf?la=en\&vs=1406.

United Nations Development Programme. (2020). UNDP Turkey Gender Equality Strategy 2017-2020. Retrieved from https://www.tr.undp.org/content/turkey/en/home/library/corporatereports/genderstrategy-2017-2020.html.

United Nations High Commissioner for Refugees. (2017). UNHCR Statistical Yearbook 2017. Retrieved from https://www.unhcr.org/en-us/statistics/country/59b294387/unhcr-statistical-yearbook-201515th-edition.html.

Vazquez-Vazquez, A. et al. (2020). The impact of the Covid-19 lockdown on the experiences and feeding practices of new mothers in the UK: Preliminary data from the COVID-19 New Mum Study. Appetite (Article in Press) https://doi.org/10.1016/j.appet.2020.104985.

Vesoulis, A. (2020). Coronavirus may disproportionately hurt the poor - and that's bad for everyone. Retrieved from https://time.com/5800930/how-coronavirus-will-hurt-the-poor/ (Access date: March 12, 2021 )

White, C. \& Nafilyan, V. (2020). Coronavirus (COVID-19) related deaths by ethnic group, England and Wales - March 22020 to May 15 2020. Retrieved from https://www.ons.gov.uk/peoplepopulationandcommunity/birthsdeathsandmarriages/deaths/article s/coronaviruscovid19relateddeathsbyethnicgroupenglandandwales/2march2020to15may2020.

World Bank. (2021). Gender dimensions of the COVID-19 pandemic. Retrieved from http://documents1.worldbank.org/curated/en/618731587147227244/pdf/Gender-Dimensions-ofthe-COVID-19-Pandemic.pdf.

World Economic Forum. (2021). Global Gender Gap. Retrieved from https://www.weforum.org/reports/ab6795a1-960c-42b2-b3d5-587eccda6023. 